\title{
IWONA LINDSTEDT
}

UNIWERSYTET WARSZAWSKI

\section{ROMAN PALESTER JAKO PIONIER POLSKIEJ MUZYKI FILMOWEJ}

\footnotetext{
Tompozytorom polskim, którzy uważają, że się dyskwalifikują, pisząc ilustracje do filmów, pozwolę sobie przypomnieć, że do rzędu ilustratorów filmowych należą dziś już Schoenberg i Casella, Honegger i Hindemith, Rathaus i Auric, Ibert i wielu innych. Jeżeli tym asom kompozytorskim warto być ilustratorami filmowymi, może więc w ogóle warto?
}

- pisała Zofia Lissa w 1938 r. na łamach Czasu, utyskując jednocześnie, że nieliczni tylko kompozytorzy „o wyrobionym już na terenie muzyki czystej nazwisku” (Palester, Maklakiewicz) działają w tej dziedzinie, oddając pole twórcom „tzw. muzyki lekkiej”. Korygując nieco tę tezę, zauważyć trzeba, że wskazani przez Lissę de facto nie są jedynymi, którzy w okresie międzywojennym uprawiali muzykę filmową (na taką listę wpisać trzeba także m.in. Ludomira Różyckiego, Grzegorza Fitelberga, Feliksa Rybickiego, Piotra Perkowskiego, Andrzeja Panufnika, Szymona Laksa, Witolda Lutosławskiego, Michała Kondrackiego). Tym niemniej nazwisko Palestra ma w tym kręgu wyróżniające się znaczenie. Odcisnęło trwały ślad w dziejach polskiej kinematografii choćby ze względów ilościowych (co najmniej czternaście filmów zrealizowanych przed wojną, pięć powojennych), mimo iż sam kompozytor nie nadawał temu aspektowi swej twórczej działalności (podobnie jak muzyce pisanej dla teatru) większej wagi.

Przedmiotem zainteresowania w niniejszym artykule będzie jedynie pierwsza, bardzo intensywna faza współpracy Palestra z rodzimą kinematografią, na którą składają się ścieżki muzyczne pisane samodzielnie lub/i we współpracy z innymi twórcami, w tym przede wszystkim z Marianem Neuteichem, do roku 1939. Jest to bardzo specyficzny obszar badawczy, przede wszystkim ze względu na kwestie źródłowe. W przeciwieństwie do muzyki filmowej pisanej przez Palestra po II wojnie światowej nie zachowały się bowiem partytury, a główną podstawą wnioskowania o kształcie ilustracji muzycznej pozostają materiały audiowizualne. Te jednak są mocno niekompletne - aż cztery

I Zofia Lissa, „O styl muzyczny w ilustracji dźwiękowej filmów”, Czas 90 (I938) nr 201 [dodatek tygodniowy], s. II. 
(Dzikie pola, August Mocny, Nad Niemnem, Żotnierz królowej Madagaskaru) spośród zilustrowanych przez Palestra filmów fabularnych mają status dzieł zaginionych, natomiast pełne oszacowanie liczby niefikcjonalnych (dokumentalnych) filmów z umuzycznieniem jego autorstwa nie jest możliwe ze względu na fakt, że zachowało się do dziś jedynie IO-2o procent tego typu produkcji przedwojennych ${ }^{2}$. $Z$ tego względu podjęta tu próba rekonstrukcji wkładu Romana Palestra w dzieje polskiego kina dźwiękowego lat trzydziestych odwołuje się w dużej mierze do źródeł pośrednich: przede wszystkim do materiałów prasowych z recenzjami, omówieniami filmów i ich reklamą, ale też do wspomnień i dokumentów sprawozdawczych. $\mathrm{Z}$ muzykologicznego punktu widzenia, najważniejszym zadaniem pozostaje określenie funkcji i znaczenia muzyki Palestra w konkretnych filmach, jej idiomatycznych cech, charakterystyka języka dźwiękowego, którym kompozytor się posługiwał oraz próba rozpoznania, w jakim stosunku pozostaje on do środków konstytuujących równoległy dorobek kompozytora w zakresie muzyki autonomicznej. Tym niemniej, ze względu na syntetyczny charakter niniejszego artykułu, szczegółowa analiza tej problematyki została ograniczona do jednego przykładu. Wśród celów poniższego wywodu sytuuje się też próba zarysowania panoramy recepcji filmowej muzyki Palestra w międzywojennym środowisku kulturowym oraz określenia zasad jego współpracy z innymi kompozytorami, z którymi wchodził w twórcze alianse przy pracy dla polskiego kina.

Swój flirt z X Muzą Palester rozpoczął w okresie odpowiadającym wczesnej fazie rozwoju polskiego filmu dźwiękowego, szczególnie efektywnie współpracując z młodym, obiecującym reżyserem Józefem Lejtesem (I90I-83). W I932 r. na ekrany wszedł jego film pt. Dzikie pola, ukazujący perypetie siedmiu byłych żołnierzy, którzy po ucieczce z niewoli znajdują schronienie w samotnej zagrodzie na pustkowiu. „Myślą przewodnią filmu jest zmaganie się uczestników wojny, już po odtrąbieniu pokoju, ze straszliwymi skutkami schamienia duszy w ogniu walk i chaosu wojennego" - mówił w wywiadzie jeden ze współautorów scenariusza ${ }^{3}$. Niewiele wiadomo o warstwie muzycznej filmu, gdyż jego kopia się nie zachowała, ale najwyraźniej jej komponowanie poprzedzone zostało specjalnymi studiami folklorystycznymi. W I93I r. tygodnik Kino donosił bowiem w relacji z planu:

Muzyka filmowa też ma swego przedstawiciela. Aby folklor i prymityw poleski nic nie utracił ze swej typowości, bawi tu wraz z zespołem znany kompozytor Roman Palester, badający pieśni ludowe. Wiele wymaga to żmudnych zabiegów: chóry dziewcząt, dzieci i starców, niekiedy poszczególne tylko osoby przesuwają się przez kalejdoskop badań muzycznych. Można sobie wyobrazić, że muzyka do tego filmu będzie naprawdę swojska i typowa ${ }^{4}$.

2 Małgorzata Hendrykowska, Historia polskiego filmu dokumentalnego (I896-I944), Poznań 20I5, s. 9. Ponadto napisy do tych filmów często pozbawione były informacji o autorze muzyki.

3 Zygmunt Schindler, „Rozmowa o Dzikich Polach w Berlinie”, Kino 2 (I93I) nr 38, s. 7.

4 M., "Jak się nakręca Dzikie Pola", Kino 2 (I93I) nr 43, s. 7. 
Krytyka przyjęła film z pewną rezerwą, doceniając jednocześnie wartość artystyczną epickiej wizji reżysera. Popremierowe reakcje krytyki odsłaniają też problem innego rodzaju - kwestię jakości technicznej dźwięku, która pozostawiała wiele do życzenia i siłą rzeczy uniemożliwiała rzetelną ocenę muzyki. Stefania Zahorska na łamach Wiadomości Literackich pisała na przykład:

Bóg ją wie, jaka ona [muzyka - I.L.] jest naprawdę. Aparat ryczał, buczał, zgrzytał, wył niekiedy układała się z tego jakaś melodia, niekiedy jakiś brzuchomówca jęczał: „Więc ty ją naprawdę tak kochasz?”. Mam jednak wrażenie, że winę ponosi nie tylko zła aparatura, lecz że w ogóle całe ujęcie dźwiękowe nie stoi na poziomies.

Tym niemniej dzięki prasowym przekazom na temat muzyki, czy też właściwie piosenek do tego filmu wiemy nieco więcej. Recenzent Kina zanotował następujące na ten temat spostrzeżenia:

Usterki techniczne w realizacji Dzikich pól nie pozwoliły nam w dostateczny sposób poznać wybitnego talentu kompozytorskiego Romana Palestra i jego pomocnika Neuteicha. Ta spółka skomponowała dwie, istotnie znakomite piosenki: Mania i Minione lata, pierwsza wesoła, druga zaś - romans. Niżej podpisany poznał te dwa utwory w interpretacji fortepianowej, a nie z taśmy filmowej i dlatego ocena ich idzie nie z punktu widzenia wartości filmu, a z naturalnej wartości samych kompozycji. Palester, kompozytor o dużym wykształceniu muzycznym i wybitnym talencie, jest ze wszech miar indywidualistą. Nie jest skłonny do... reminiscencji, daleki od jakichkolwiek wzorów, mówiąc najoględniej, od szablonu. Szkoda zatem, zwłaszcza dla muzykalnych słuchaczy, że jego kompozycje natrafity na niefortunną realizację

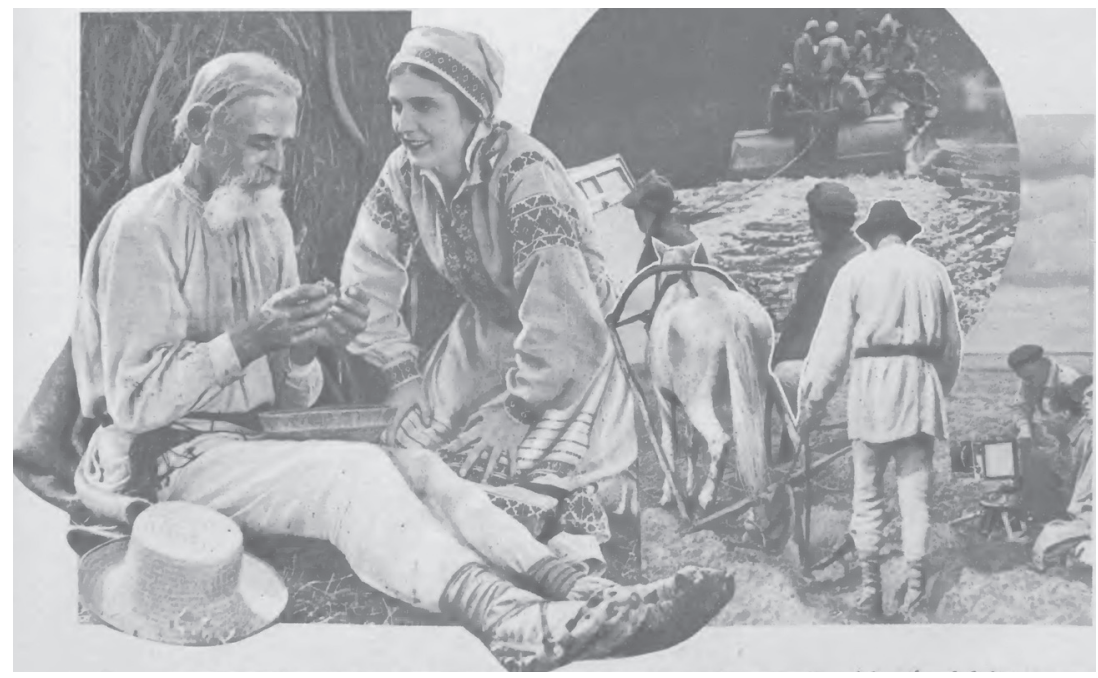

Il. I. Fotosy z filmu Dzikie pola, w: Kino 2 (1931) nr 43, s. 7.

5 Stefania Zahorska, „Kronika filmowa”, Wiadomości Literackie 9 (I932) nr I3, s. Io.

6 M.S., „Polskie piosenki w polskich filmach”, Kino 3 (I932) nr 2I, s. 5. 
Tworzona przez Palestra muzyka filmowa miała zatem już w pierwszym akcie swego zaistnienia dwa podstawowe komponenty: ilustracyjny i piosenkowy, co pozostało często powtarzającą się praktyką

Osoba Mariana Neuteicha (I890-1943) odgrywa kluczową rolę w przebiegu kariery filmowej Palestra przed wybuchem II wojny światowej. Obydwaj stworzyli wspólnie oprawę muzyczną do pięciu filmów. Wobec braku partytur i bardzo ogólnego charakteru informacji wnoszonych przez napisy (zwykle był to układ alfabetyczny), nawet w obliczu wyżej cytowanej opinii, trudno z pewnością stwierdzić, jak wyglądał rzeczywisty podział ról i kompetencji przy pracy nad tymi ilustracjami. Wnioskować można jedynie na podstawie poszlak. Jeśli jednak podążymy za wskazówką daną przez Wiesława Stradomskiego, jakoby Neuteich „pomagał wielu początkującym w komponowaniu muzyki filmowej"7, przypuszczać można, że wspomagał ich na przykład bardziej wnikliwą znajomością specyfiki sztuki filmowej. Domysł ten znajduje potwierdzenie w działalności publicystycznej Neuteicha, którego artykuł ogłoszony na łamach czasopisma Film Artystyczny („f.a.”) stanowi ważny wkład we wczesną fazę polskiej refleksji nad muzyką filmową i dowodzi tezy o pełnym równouprawnieniu czynników wizualnych i akustycznych w filmie dźwiękowym ${ }^{8}$. Zaproszenie tego twórcy do przedsięwzięcia firmowanego przez Stefana i Franciszkę Themersonów świadczy o renomie, jaką musiał cieszyć się w środowisku filmowców.

Tandem Palester-Neuteich firmował także zrealizowany w I934 r. kolejny film Lejtesa o tematyce historycznej pt. Mtody las. Zarówno w ocenie krytyki, jak i publiczności była to produkcja wyróżniająca się na tle pozostałej polskiej twórczości filmowej. Film wygrał plebiscyt czytelników Kina, a znawców zachwycił walorami warsztatowymi (bardzo filmowy sposób narracji) i artystycznymi (gra aktorska). Opowieść rozgrywającą się w niespokojnym I905 r. w jednym z warszawskich gimnazjów, w którym narasta ideowy konflikt między rosyjskimi nauczycielami a konspirującą młodzieżą, rozpoczyna muzyka prezentowana na tle napisów. Jej początkowy dramatyzm (z wykorzystaniem reminiscencji polskiego hymnu narodowego) przechodzi w liryzm tematu utrzymanego w późnoromantycznej konwencji symfonicznej. Te dwa stany wyrazowe przewijają się w muzycznym akompaniamencie do obrazu, towarzysząc zarówno zdarzeniom pełnym emocjonalnego napięcia, jak i wątkowi miłosnemu Stefana i Wandy (Adam Brodzisz i Maria Bogda) czy scenom plenerowym. „Muzyka przez cały czas prosta i ładna, ściśle dostosowana do akcji” - pisał Wojciech Wasiutyński na łamach Prosto z mostu9. Być może w sformułowaniu tym kryje się także komentarz do przejmującej sceny ukazującej za pośrednictwem

7 Wiesław Stradomski, „Realizatorzy filmów”, w: Historia filmu polskiego, t. II, I930-I939, Warszawa I988, s. 29. Neuteich współpracował też m.in. z Piotrem Perkowskim przy filmie Wielkomiejski mrok, 1932, i z Michałem Kondrackim przy filmie Dziewczyna szuka mitości, 1938.

8 Marian Neuteich, „Muzyka w filmie dźwiękowym”, Film Artystyczny I (I937) nr 2.

9 Wojciech Wasiutyński, „Młody las”, Prosto z mostu I (I935) nr I, s. 8. 
muzyki przeżycia wewnętrzne ubogiej matki głównego bohatera filmu Adama Walczaka (w tej roli Mieczysław Cybulski) w związku z groźbą usunięcia syna ze szkoły i złożoną mu przez szkolne władze propozycją „nie do odrzucenia”.

Wspólną pracą Palestra i Neuteicha dla Lejtesa był też Dzień wielkiej przygody z 1935 r., który zdobył puchar Confederazione fascista degli industriali (Faszystowskiej Konfederacji Przemysłowców) na Biennale Filmowym w Wenecji. Walorem filmu były niewątpliwie piękne zdjęcia ośnieżonych gór i lasów wykonane przez Seweryna Steinwurzla ${ }^{\text {Io }}$. Sceneria i tematyka tego filmu opowiadająca o przygodzie harcerzy, którzy podczas tatrzańskiej wycieczki unieszkodliwiają bandę przemytników, musiała być Palestrowi bardzo bliska, ze względu na własne przeżycia z czasów gimnazjalnych. Harcerstwu poświęcał się wszak wówczas szczególnie, biorąc udział w tzw. obozach wędrownych na karpackich szlakach, a ich wspomnienie przekuł - jak wiadomo w dźwięki Tańca z Osmotody. Ponieważ kopia, uważanego długo za zaginiony, Dnia wielkiej przygody została odnaleziona w archiwum Instytutu Polskiego i Muzeum im. gen. Sikorskiego w Londynie, prawdopodobnie wkrótce można będzie powiedzieć więcej o własnościach muzyki. Z przekazów prasowych wiadomo jedynie, że ilustracja muzyczna była „oparta na motywach ludowych” "II, choć z drugiej strony narzekano, że muzyka do tego filmu jest zbyt trudna i niezbyt przystająca do jego wymowy. Dla Wiadomości Filmowych pisał np. Andrzej Ruszkowski:

Skoro już jesteśmy przy wadach, to dodajmy, że trudno pogodzić się z koncepcją pięknej skądinąd ilustracji muzycznej Palestra i Neuteicha. Zamiast dość ciężkawej i nawet trochę patetycznej muzyki, wolelibyśmy coś pogodniejszego, młodszego, a przez to bardziej odpowiadającego optymistycznemu nastrojowi filmu ${ }^{12}$.

Zanim mowa będzie o następnych przykładach współpracy Palestra i Neuteicha z Józefem Lejtesem warto uświadomić sobie, jaki stosunek miał ten reżyser do filmu dźwiękowego. Początkowo nieufny, utrzymany w obawie, że słowo i dźwięk nałożą wspaniale rozwijającej się sztuce filmowej kajdany. Ale z czasem przekształcił się on w oryginalną koncepcję „trzeciego wymiaru”, kojarzącego niezależne od siebie elementy dźwiękowe i wizualne w bogatszą i głębszą niż w filmie niemym jakość.

W filmie dźwiękowym - pisał Lejtes w liście do Barbary Armatys - reżyser poprzez dźwięk dostał także środki, przy pomocy których jest on w stanie szukać i stworzyć nową treść. Treść, którą może on stworzyć przy pomocy nowej techniki (zamiana dźwięków itd.), w której nie chodzi, jak to było dotychczas, o pewną ciaggłość wypadków dla stworzenia dramatu, lecz jednoczesne zestawienie elementów, przeciwstawienie, konflikt itd. ${ }^{13}$.

Zob. np.: Stefania Zahorska, „Kronika filmowa”, Wiadomości Literackie I2 (1935) nr 37, s. 5.

Ace, „Kino”, Kuźnia Mtodych 4 (1935) nr I4, s. 4.

I2 Andrzej Ruszkowski, „Nowy ton w produkcji polskiej”, Wiadomości Filmowe 3 (1935) nr 17, s. I2.

I3

„Listy Józefa Lejtesa do Barbary i Leszka Armatysów”, Kino (1984) nr I, s. 20. 


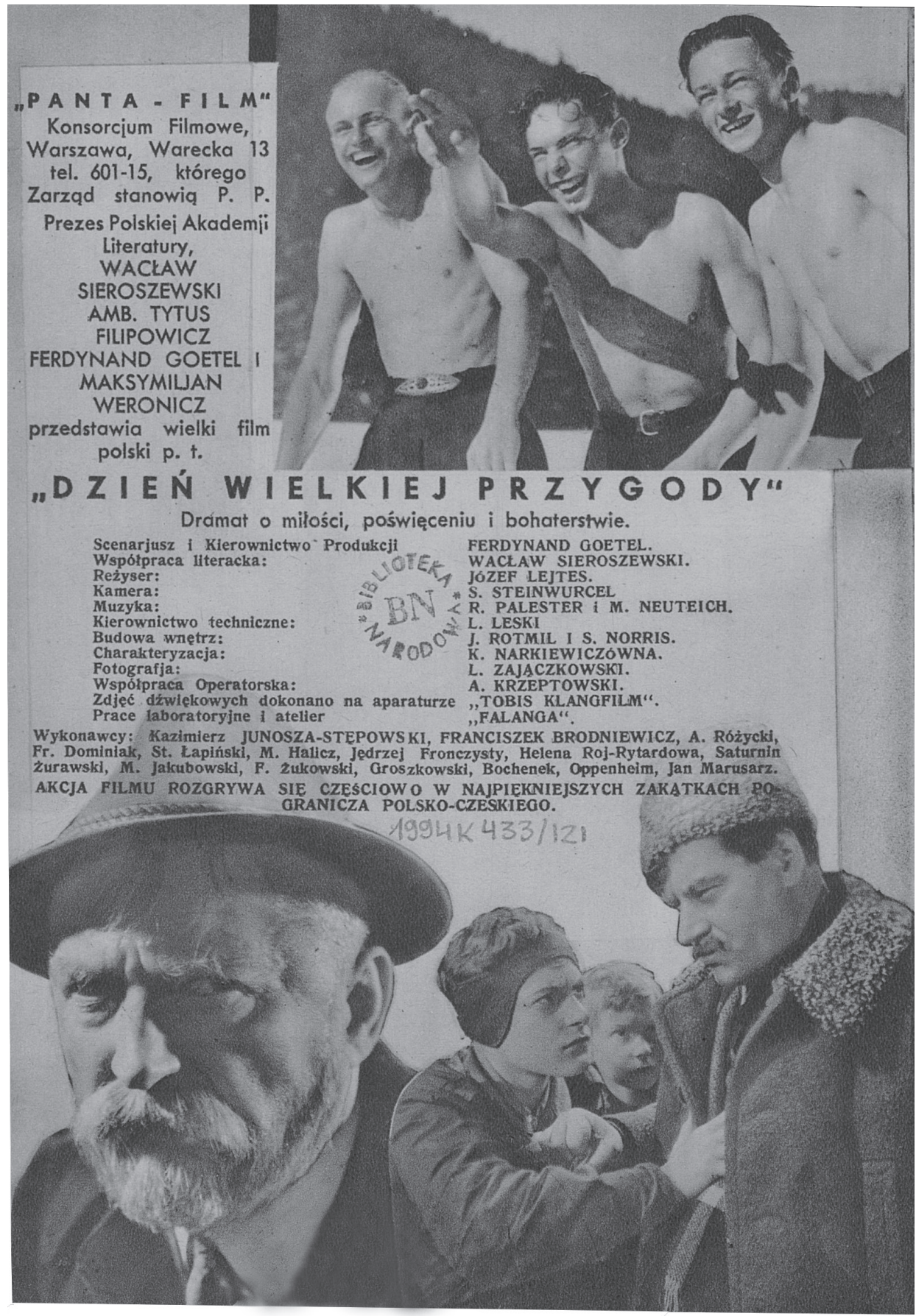

Il. 2. Program filmowy Dzień wielkiej przygody. 
Skorzystał z tych możliwości na przykład w Róży z 1936 r., sięgając po tekst Stefana Żeromskiego, z którego wykrojono scenariusz. Scena zamachu na rosyjskiego gubernatora została tu bowiem udźwiękowiona i umuzyczniona w sposób wyrafinowany. Jak wspominał reżyser:

Zamiast [...] procedury zamachu, karety z gubernatorem, bomby, policji, popłochu itd. całą scenę rozplanowałem w pokoju nauczycielki muzyki (Lena Żelichowska), u której zebrali się zamachowcy. W czasie, gdy nauczycielka grała Etiudę Rewolucyjną Chopina, aparat koncentrował się na rozmaitych zbliżeniach zasłuchanych zamachowców, na rękach pianistki, na klawiaturze. Zamiast ostatniego akordu muzycznego podłożyłem dźwięk wybuchu bomby. Następnie na twarzach zastygłych zamachowców słyszałem dźwięki gwizdków policyjnych, kopyt końskich, tupot biegnących ludzi [...] Impakt tej inscenizacji był do tego stopnia wstrząsający, że nawet cenzura chciała usunąć całą scenę ${ }^{\mathrm{I} 4}$.

Choć Lejtes o tym nie wspomina, zapewne Palester z Neuteichem mieli swój udział w kreacji tej sceny. Niejedyne to zresztą w filmie ciekawe rozwiązanie muzyczne. Jest nim też scena egzekucji spiskowców przy wtórze werbli, a nade wszystko prolog Róży. Muzyka, pośród której przebłyskują motywy polskiego hymnu narodowego, pełna falujących, „glissandowych” biegników instrumentów smyczkowych i dętych, pełni tu rolę wyrazowego wzmocnienia dla obrazu śnieżnej burzy u bram warszawskiej Cytadeli, uzupełnianego realistycznymi świstami hulającego wiatru. Scena ta należy do najistotniejszych elementów symbolicznych filmu Lejtesa i związana jest z zabiegiem trzykrotnego powtórzenia obrazu wybuchu Cytadeli, który - prócz przywołanej wyżej sceny z Etiuda rewolucyjną Chopina - powraca też na końcu dzieła. Za pomocą filmowych środków wyrazu zabieg ten projektuje siłę rewolucji, jej przebieg i skutki ${ }^{\mathrm{I5}}$.

Wśród zrealizowanych przez Józefa Lejtesa adaptacji dzieł literackich ważną pozycję zajmują Dziewczęta z Nowolipek według powieści Poli Gojawiczyńskiej pod tym samym tytułem. Sukces powstałego w I937 r. filmu utwierdziła sama pisarka, uznając, że osiągnięty efekt jest w pełni zadowalający, a film oddaje doskonale nastrój jej opowieści, skoncentrowanej wokół dramatycznych losów czterech dziewcząt z warszawskiego Muranowa (w obsadzie filmu: Bronka - Elżbieta Barszczewska, Franka - Jadwiga Andrzejewska, Amelka - Tamara Wiszniewska, Kwiryna - Anna Jaraczówna). Realizację tego zadania wydatnie wsparła ścieżka muzyczna autorstwa Palestra i Neuteicha. Jako że osią dramaturgiczną filmu reżyser uczynił studzienne podwórko kamienicy, w tej właśnie przestrzeni koncentruje się muzyka pochodząca ze świata przedstawionego. Obok odgłosów codzienności, okrzyków czy dziecięcych wyliczanek rozbrzmiewają tu m.in. wątki muzyczne ze skarbnicy miejskiego folkloru, jak gra kataryniarza i marszowy temat przewodni filmu w wykonaniu amatorskiego

I4 Ibid.

I5 Zob. na ten temat Wojciech Otto, Literatura i film w kulturze dwudziestolecia międzywojennego, Poznań 2007, s. 100 . 
zespołu Mietka (brata Bronki) czy też muzyki popularnej, jak dobiegający z okna mieszkania „artystki” cygański romans ${ }^{16}$.

Na uwagę zasługują przykłady łączenia muzyki diegetycznej z niediegetyczną, jak choćby w scenie wyjazdu głównych bohaterów na majówkę. Symfoniczny akompaniament do obrazu pędzącego zaprzęgu konnego przekształca się tu płynnie w opracowanie głównego tematu ze śpiewem, w scenie tanecznej zmienia się rodzaj rytmu, a potem znów w płynnym montażu powraca muzyka spoza ekranu towarzysząca zabawom w plenerze. Istotne wydaje się przy tym, że opracowanie muzyczne tych scen, podąża dość wiernie za narracją Gojawiczyńskiej, która pisała o dźwiękach dziarskiego marsza podczas podróży wozem, o śpiewaniu popularnych melodii i o walcu Piękne róże, „który często grali na podwórzach Nowolipek kataryniarze” ${ }^{17}$, przy którym wirowały na Bielanach młode pary. Można także rzec, że sposób funkcjonowania muzyki w tym filmie wspierał chwaloną przez krytykę reżyserską umiejętność ukazywania „bezpośredniości i prawdy, przy jednoczesnym unikaniu naturalizmu i stawianiu kropek nad i" ${ }^{18}$.

Adaptacją współczesnej literatury polskiej był także film Ludzie Wisty (1938) wyreżyserowany przez Aleksandra Forda i Aleksandra Zarzyckiego, który okazał się ostatnim wspólnym przedsięwzięciem Palestra i Neuteicha. Powieść Heleny Boguszewskiej i Jerzego Kornackiego pt. Wista zainspirowała dzieło ukazujące, jak głosi deklaracja zawarta w początkowych napisach, „egzotyczny świat ludzi Wisły” i ich codzienny trud. Film ten, podobnie jak Dziewczęta z Nowolipek, krytyka uznała za wydarzenie w dziejach polskiej kultury filmowej. Chwalono zwłaszcza aktorstwo, a także zdjęcia Stanisława Lipińskiego i montaż. Po premierze pisano na przykład: „Ludzi Wisty można uznać po Mtodym lesie i Dziewczętach z Nowolipek za dalszy etap rozwoju prawdziwej sztuki filmowej w Polsce” ${ }^{\text {I9 }}$. Muzyka doczekała się niewielu komentarzy, a przecież na całość filmu miała wpływ istotny, wzmacniając sugestywność ujęć i wnosząc w utrzymaną zasadniczo w liryczno-refleksyjnym tonie historię niekłamany wdzięk i element humoru. Znakomita jest na przykład scena rozmowy jednej z głównych bohaterek, starej Matyjaski (w tej roli Stanisława Wysocka) z porzuconym przed laty mężem. Kobieta chce pożyczyć od niego Io tysięcy złotych na zakup barki (berlinki) i w determinacji grozi mu ujawnieniem bigamii, której się dopuścił, podczas gdy w tle, z uruchomionej przez synka pozytywki, rozbrzmiewa Marsz weselny Mendelssohna. Wśród humorystycznych aspektów tej ilustracji muzycznej zwracają też uwagę rozbiegane dźwięki fagotu, które towarzyszą na przykład spotkaniu złodziejaszka Aleksego (Jerzy Pichelski) i szypra Dobrziałkowskiego (Ka-

I6 Przy rozstaniu tak rzewnie ptakata... z muzyką Aleksandra Dawidowa i polskimi słowami Stanisława Przesmyckiego.

I7 Pola Gojawiczyńska, Dziewczęta z Nowolipek, [Gdańsk] 200I, s. 8I.

I8 Stefania Heymanowa, „Z życia ekranu”, Bluszcz 70 (I937) nr 48, s. 566.

I9 Józef Kuroczycki, „Nowe filmy”, Wiadomości Literackie I5 (I938) nr 34, s. 34. 
zimierz Opaliński), nieco „ciamajdowatego” pomocnika Matyjaski na przystani, antycypując kolejne wydarzenia: jedną z narzuconych przez producenta, mających film „uatrakcyjnić” scen pijackich ${ }^{20}$ oraz jej konsekwencje.

Dzięki muzyce, chwilami mocno dysonansowej, wykorzystującej brzmienie dzwonów, wstrząsająca jest rozbudowana i rozciągnięta w czasie scena pogrzebu Julci - siostry Anny (Ina Benita), wypełniona przez obrazy stypy w knajpie i - na zbliżeniach - gesty rozpaczy jej osieroconego męża Zygmunta, którego w końcu Anna ratuje przed samobójstwem. Podążając za sugestią Zofii Helman, przypuszczać można ponadto, że praca przy Ludziach Wisty była właśnie jednym z tych doświadczeń teatralno-filmowych Palestra, z których wyrosła jego powojenna kantata Wista do słów Stefana Żeromskiego ${ }^{21}$. Zwłaszcza przy świadomości, że konsekwencją ingerencji producenta w film Forda i Zarzyckiego były też cięcia lirycznych scen fotograficznych ukazujących piękno rzeki i nadwiślańskiego krajobrazu, którym towarzyszyła zapewne wyrafinowana muzycznie ilustracja, być może - jak muzyka do kantaty - nie unikająca elementów malarstwa dźwiękowego.

Ponadto w ścieżkę muzyczną Ludzi Wisty wplecione są w tym filmie cztery piosenki, do których teksty napisał Władysław Broniewski. Co ciekawe, poeta ten był też autorem słów dwóch piosenek z wcześniejszego filmu Palestra-Neuteicha - Dnia wielkiej przygody, ponadto jego utwory podpisywane pseudonimem B. Wit usłyszeć można w takich przedwojennych filmach, jak Barbara Radziwittówna, Dziewczyna szuka mitości i Strachy ${ }^{22}$. W Ludziach Wisty szczególną rolę odgrywa piosenka o bosmanie (Wiślane wody), śpiewana przez Aleksego, poprzedzona rzewnym skrzypcowym solem i charakteryzująca się kontrastującym wyrazistym, skocznym rytmem refrenu.

Wesoło żyć, wesoło żyć,

Berlinka z prądem płynie,

W Toruniu, w Gdańsku można pić,

W Warszawie i w Modlinie,

Na wodę ster i ster na ląd,

Spieniona fala, bystry prąd,

Za burtą słychać tarcie kier,

I jeszcze raz na wodę ster.

Wprawdzie nie wiemy na pewno, który ze współpracujących ze sobą kompozytorów był autorem muzyki do powyższych słów, lecz skądinąd wiadomo, że Roman Palester doskonale radził sobie z komponowaniem piosenek. Najsłynniejszą i najszerzej rozpoznawalną jest ta pod tytułem Baby, ach te baby, która dzięki interpretacji Eugeniusza Bodo zrobiła furorę. $Z$ refrenem:

Zob. Stanisław Janicki, Aleksander Ford, Warszawa 1967, s. 37.

Zofia Helman, Roman Palester. Twórca i dzieto, Kraków 1999, s. 137.

Regina Kaźmierczak, „Broniewski i film”, w: „Wierszem kocham i wierszem cierpię”. Studia - referaty materiaty, red. Ewa Lewandowska, Maria Zalewska-Mikulska, Płock 1998, s. 54. 
Baby,

Ach! te baby,

Człek by je łyżkami jadł.

Tęgi chłop, co lekko w ręku łamie sztaby

Względem baby jest tak, jak dziecko całkiem słaby.

Baby,

Ach! te baby,

Czym by bez nich był ten świat...

Co tu łgać, co tu kryć,

Spróbuj bez baby żyć,

Gdy ci uda się taka sztuka, toś jest chwat!

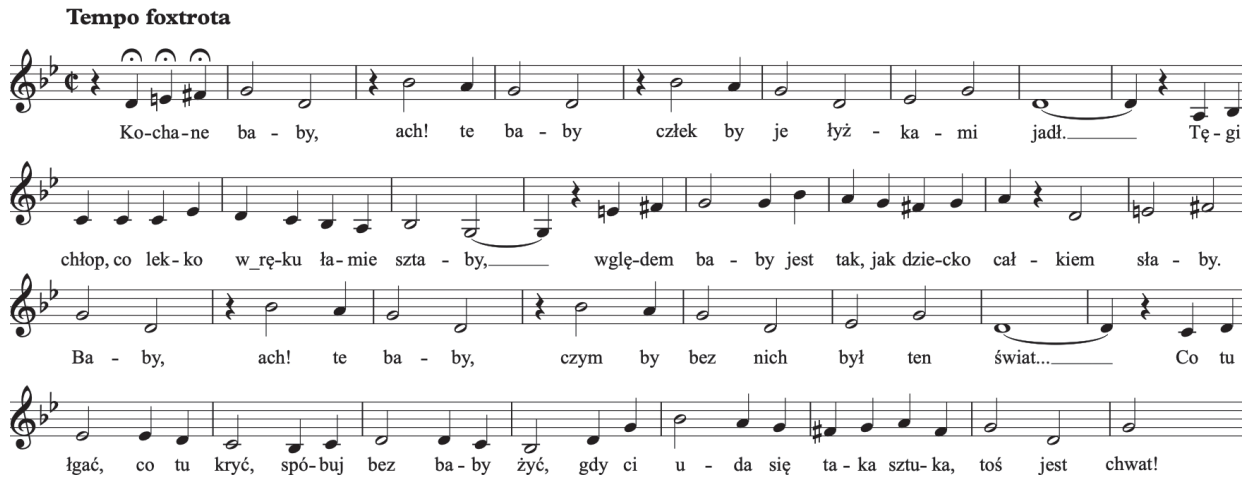

Przykł. I. Refren piosenki Baby, ach te baby.

Z tekstem tej piosenki wiąże się zabawna anegdota utrwalona na łamach tygodnika artystycznego Trubadur Warszawy. Kompozytor po zapoznaniu się z tekstem Nela miał zażartować: „Co pan za herezje wypisał o dobroci bab, przecież nawet dzieciak wie, że z wszystkich bab są dobre tylko... pieczone"23.

Ten słynny przebój, włączony do repertuaru m.in. Adama Astona, Tadeusza Faliszewskiego czy Duetu Corda, wielokrotnie nagrywany na płyty, powstał do wyprodukowanego w 1933 r. przez inżyniera Stefana Gulanickiego filmu Zabawka. „Nowy filar polskiego przemysłu filmowego” - jak nazwała Gulanickiego prasa - przystąpił do dzieła z rozmachem, angażując „wyborowe siły aktorskie” z Bodo i Zulą Pogorzelską na czele, lecz główne role rezerwując dla siebie i swej protegowanej-Almy $\mathrm{Kar}^{24}$. Scenarzystów tej historii kobiety fatalnej, kabaretowej tancerki Lulu i trzech uwiedzionych przez nią mężczyzn, inspirować miał niemiecki niemy film Lulu (Die Büchse der Pandora) w reżyserii Georga Wilhelma Pabsta, lecz końcowy rezultat okazał się dość wulgarny i Zabawka zyskała niezbyt przychylne oceny krytyki. Stefania Zahor-

23 Harry Ellen, „Plotki, ploteczki”, Trubadur Warszawy 26 (1934) nr 37, s. 5.

24 „Rozmowa z inż. St. Gulanickim realizatorem filmu Zabawka”, Kino dla Wszystkich 8 (1933) nr 37, s. II. 
ska uznała wyreżyserowany przez Michała Waszyńskiego film wręcz za „erotomańską bzdurę z panem, paniczem i chłopakiem, z podrygami trzech samców i jednej niestrawnej samicy” ${ }^{25}$. Jednak dostrzeżono też jego zalety - w tym „naturalnie brzmiące dialogi” Konrada Toma oraz „finezyjną oprawę muzyczną p. Palestra” ${ }^{26}$. Jej podstawą jest bez wątpienia atrakcyjność piosenek do słów Jerzego Nela, w tym slow-foxa To mi wystarczy - które sława Bab całkowicie przyćmiła. Z następującym refrenem:

To mi wystarczy! Wystarczy mi!

To mi się stale po nocach śni...

Choć trochę serca, miłości,

Spełnienie marzeń i snów.

I żeby człowiek naprawdę czuł,

Że ktoś go kocha, że weźmie wpół...

I powie krótko, najprościej,

Choć tych parę czułych słów.

Ja za to oddam zabawy i taneczny szał,

By tylko los był łaskawy

I czyjeś serce dał.

To mi wystarczy! Wystarczy mi.

To mi się stale po nocach śni...

Trochę uczucia, miłości,

I to wystarczy mi.
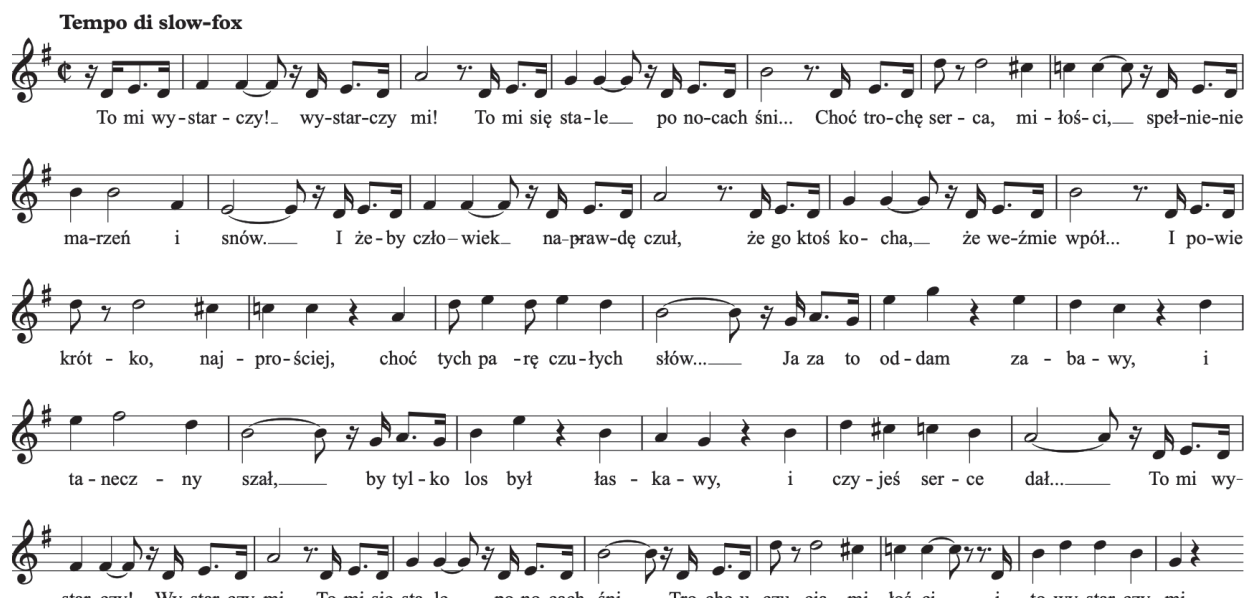

star czy! Wy-star-czy mi... To mi się sta-le_ po no-cach śni..._ Tro-chę u-czu-cia, mi - łoś-ci,_ i to wy-star-czy mi.

Przykł. 2. Refren piosenki To mi wystarczy.

25 Stefania Zahorska, „Kronika filmowa: Zabawka”, Wiadomości Literackie Io (1933) nr 56, s. 4.

26 Leon Brun, „Zabawka, nowy film polski”, Kino 4 (I933) nr 52, s. 5. 
W programie filmowym jako jeden z trzech „przebojów”, które ukazały się nakładem Gebethnera i Wolffa - „do nabycia we wszystkich składach nut” ${ }^{27}$ - zaanonsowana została także piosenka-tango pt. Nie mówmy o tem więcej, lecz nie jest ona najprawdopodobniej dziełem Palestra. Została bowiem nagrana m.in. przez Orkiestrę Taneczną „Odeon” pod dyrekcją Jerzego Gerta w 1937 r., jako dzieło Władysława Szlengela, Józefa Lipskiego i Beno Gobena ${ }^{28}$. W filmie Waszyńskiego rozbrzmiewa dyskretnie jako muzyka taneczna w scenie przyjęcia we dworze hrabiego Latoszyńskiego, podczas gdy - o czym jeszcze będzie mowa - konstytutywny materiał muzyczny całości stanowią Baby, ach te baby i To mi wystarczy.

Historia zaangażowania kompozytora w powyższe stricte komercyjne przedsięwzięcie filmowe wydaje się tym ciekawsza, im silniej uświadomimy sobie, że kompozytor zadeklarował się jako przeciwnik kiczowatej muzyki „lekkiej” swych czasów. Miał o niej zdanie wręcz druzgocące, wynikające jednak przede wszystkim z oceny niskich kompetencji jej twórców i niechęci zarówno do masowej kultury muzycznej, jak i do brutalnej merkantylizacji tej dziedziny twórczości:

Wiemy wszyscy, jakim potwornym kiczem jest dzisiejsza muzyka „lekka”, to zbiorowisko tang, foxtrotów i walców, ordynarne, psujące smak szerokiej publiczności i wyrządzające istotnej kulturze muzycznej nieobliczalne szkody. Nie wszystkim wiadomo, że ten genre muzyczny przynosi swoim twórcom, przeważnie ludziom bez talentu i wykształcenia, ludziom skrajnie merkantylnym, eksploatującym bez skrupułów tę złotodajną żyłę, kolosalne dochody. Wydaje mi się, że byłoby rzeczą słuszną wszelką działalność muzyczną z pod tego znaku (przede wszystkim kompozytorów, wydawców, lokale dancingowe i płyty gramofonowe) obłożyć ostrym podatkiem, a powstały w ten sposób fundusz przeznaczyć na rozwinięcie działalności syndykatu na konkretnych i szerokich podstawach ${ }^{29}$.

Jednak piosenki pisał, nie tylko do filmów, lecz także - podobnie jak Szymon Laks - m.in. dla gwiazdy pieśniarstwa kabaretowego, Toli Korian ${ }^{30}$ czy też przeznaczone na potrzeby teatru. Przykładem popularności jednej z nich jest opublikowany tekst nutowy (aranżacja fortepianowa dokonana przez Zygmunta Wiehlera) walca angielskiego pt. Noca... śpiewanego przez Janinę Brochwiczównę w grotesce satyrycznej Porucznik Przecinek Franka Maara ${ }^{3 \mathrm{I}}$ wystawianej w Teatrze

Zob. program filmu na http://www.nitrofilm.pl/strona/lang:pl/filmy/film_info/4o/zabawka.html, dostęp 7 I 2019. Nuty utworów To mi wystarczy i Baby, ach te baby w aranżacji Władysława Eigera ukazały się w serii „Co śpiewa Warszawa” (nr 233 i 234).

28 Beno Goben, wł. Bernard Beniamin Gotfrajd (także Gotfried, Gorfrajt). Zob. Leon Tadeusz Błaszczyk, Żydzi w kulturze muzycznej ziem polskich w XIX i XX wieku. Stownik biograficzny, Warszawa 20I4, s. 92. Zob.: też https://staremelodie.pl/piosenka/IIII/Nie_mowmy_wiecej_o_tym, dostęp 7 I 2019.

29 Chodziło o syndykat państwowy centralizujący/regulujący wszystkie sprawy muzyczne, zob.: Roman Palester, „Zasadnicze zagadnienia współczesnej kultury muzycznej w Polsce. Odpowiedź na ankietę”, Muzyka Polska I (1934) nr 2, s. I24.

30 Zob.: Tola Korian. Artystka stowa i pieśni, red. Katarzyna Feicher, Londyn 1984, s. 68.

3I Warszawa 1933, w serii Co śpiewa Warszawa, nr 215. 
Polskim w Warszawie w $1933 \mathrm{r}^{32}$. Niepozbawione podstaw jest zatem szukanie odpowiedzi na pytanie o motywy przystąpienia Palestra do grona realizatorów Zabawki w realiach finansowych branżowego kina polskiego lat trzydziestych. Edward Zajiček podaje bowiem, że wynagrodzenie kompozytora mieściło się w granicach 2-4 tysięcy złotych, a przy tym „najbardziej intratne były piosenki. Jeśli stawały się przebojami i przynosiły tantiemy z ZAIKS-u opłacało się je pisać nawet za darmo" ${ }^{3}$. Nie da się jednak wykluczyć, że własnym wytworom muzyki lekkiej Palester nadawał jakiś szczególny rodzaj „misji” przeciwdziałającej szkodom, jakie wyrządzała polskiemu filmowi praktyka oddawania ilustracji dźwiękowej filmów w ręce dyletantów.

Obok Zabawki, status samodzielnych projektów muzyczno-filmowych Palestra mają także ścieżki muzyczne do dwóch filmów z 1939 r. - Żotnierza Królowej Madagaskaru Jerzego Zarzyckiego oraz Nad Niemnem Wandy Jakubowskiej i Karola Szołowskiego. Obydwa filmy zostały całkowicie ukończone i - jak wiemy z prasowych zapowiedzi - przeznaczone do eksploatacji w „najwytworniejszych kinach stołecznych”, m.in. „Colosseum”, „Światowidzie” i „Imperialu”34. Nad pierwszym z wymienionych tytułów Palester pracował w ostatnich przedwojennych miesiącach. „Wybuch wojny zaskoczył nas mniej więcej w połowie roboty i po jakim-takim ułożeniu się stosunków w okupowanej Warszawie, wypadło nam z Zarzyckim powrócić do tego filmu. Ale o tym później” - pisał kompozytor we wspomnieniach okupacyjnych ${ }^{35}$, lecz nie wrócił już do tego wątku. Wiadomo jednak, że wyprodukowana przez Spółdzielnię Autorów Filmowych, przerobiona przez Juliana Tuwima farsa Stanisława Dobrzańskiego była jednym z filmów, na których dokończenie i wyświetlanie w kinach zezwolił niemiecki okupant. Premiera miała miejsce w ostatnim dniu grudnia 1940 r.; film był eksploatowany także po wojnie, lecz wszystkie jego kopie uległy zniszczeniu. Dlatego trudno dziś mówić o domniemanych walorach muzyki Palestra. Pewną wskazówką pozostają informacje prasowe. W zamieszczonej w piśmie Aktualności relacji z filmowego atelier, gdzie dokonywano synchronizacji dźwiękowej, czytamy na przykład:

W niewielkim saloniku, urządzonym z przedwojennym szykiem, młoda para śpiewa w takt walca. Oczywiście - śpiewają o miłości. Amantem jest Zbigniew Rakowiecki. Jego partnerką - Karin Tiche. [...] Tańczą. Do tańca przygrywa i przyśpiewuje głośnik zawie-

Partytura tej ilustracji (z udziałem dwóch saksofonów, trąbki, puzonu, fortepianu, dwojga skrzypiec i perkusji) jest jednym z niewielu zachowanych świadectw materialnych twórczości teatralnej Palestra, zob.: Z. Helman, op. cit., s. 72.

33 Edward Zajiček „O moim filmie, za moje pieniądze nic nikomu nie będzie się śniło”, w: Zarys historii gospodarczej kinematografii polskiej, t. I, Łódź 2016, s. 49.

34 Zob.: Wiadomości Filmowe 7 (1939) nr I6, s. 8.

35 Roman Palester, „Fragmenty wspomnień z lat 1939-1945”, w: tegoż, Stuch absolutny. Niedokończona autobiografia i listy z lat wojny, opr. i komentarze Zofia Helman, Warszawa-Kraków 2017, s. 285-286. Maszynopis w Archiwum Kompozytorów Polskich Biblioteki Uniwersyteckiej w Warszawie, on-line http://www.palester.polmic.pl/index.php/pl/palester-o-sobie/wspomnienia-I939-1945, dostęp 7 I 2019. 
szony w górze opodal. Głośnik nadaje muzykę pod dyrekcją Romana Palestra i śpiewa głosem Rakowieckiego i jego partnerki. Aktorzy, tańcząc, poruszają tylko ustami, ale tak, aby słowa nadawane przez głośnik jak najdokładniej pasowały do poruszeń warg. [...] Na ulicy dolatują mnie jeszcze słowa melodyjnego walczyka: „...rankiem spotkać się - nocą rozstać się i odwrotnie, ach odwrotnie...”. Rozkoszna muzyka wymyka się gamą rozkołysanych dźwięków przez rozwarte na oścież wrota atelier filmowego ${ }^{36}$.

Gdy zaś film trafił do kinowej dystrybucji w Generalnym Gubernatorstwie, w komentarzu prasowym pisano, że na część muzyczną w filmie „położono specjalny nacisk”, a cały film „przynosi nie tylko interesującą niezwykle akcję, ale także wyróżnia się bogactwem melodii" 37 .

Ze wspomnień Jarosława Iwaszkiewicza wiemy, że Zarzycki obejrzał swój pierwszy film pełnometrażowy. „Urządziliśmy sobie tajną wyprawę do Żyrardowa i tam, niespostrzeżeni przez nikogo z ostatniego rzędu balkonu, obejrzeliśmy tego Żotnie$r z a$, po czym cichcem wróciliśmy do Brwinowa" - pisał ${ }^{8}$.

Iwaszkiewicz był ponadto, jak wynika z relacji Wandy Jakubowskiej, jedyną osobą, która obejrzała w całości film Nad Niemnem ${ }^{39}$. Losy tego przedsięwzięcia były dramatyczne. Na wieść, że Niemcy chcą film przemontować, tworząc opowieść o gnębionych przez Polaków kolonistach niemieckich w Prusach Wschodnich, zdecydowano o ukryciu pokawałkowanej kopii w różnych piwnicach na Żoliborzu, jednak po wojnie nie udało się jej odnaleźćc ${ }^{\circ}$. Zasadniczym walorem filmu ze scenariuszem Jarosława Iwaszkiewicza były bez wątpienia plenery realizowane w miejscu narodzin powieści (w Bohatyrowiczach), a także wielka staranność w odtworzeniu kostiumów z epoki, nad czym czuwał Jan Marcin Szancer, który zdał barwną relację z postępów prac na filmem czytelnikom czasopisma $A s^{4 \mathrm{I}}$. Jaka była muzyka - można się tylko domyślać.

Do dnia dzisiejszego przetrwała natomiast ilustracja muzyczna do trzeciego filmu Palestra z I939 r. - zrealizowanej przez Mieczysława Krawicza (skądinąd twórcy pierwszego polskiego filmu, którego dźwięk zarejestrowano bezpośrednio na taśmie filmowej - Każdemu wolno kochać z I933 r.) komediofarsy pt. Ja tu rządzę według sztuki Wincentego Rapackiego (syna). Podobnie jak Żotnierz Królowej Madagaskaru, także ten film dopuszczono do eksploatacji podczas okupacji (premiera odbyła się w grudniu i94I r.). Oprawa muzyczna ma jednak kształt współautorski - partnerem Palestra był w tym wypadku Władysław Dan (wł. Władysław Daniłowski, I902-2000), twórca słynnego warszawskiego chóru rewelersów i ulubiony kompozytor Hanki Ordonówny. Historia hrabiego Józia Lulewicza (Zbigniew Rakowiecki), który zatrudnia

36 Z.P., „Młodość śpiewa w walca takt... ”, Aktualności I (1939) nr 5-6, s. I7.

37 „Twórczość artystyczna w Warszawie”, Gazeta Ilustrowana. Tygodnik 2 (194I) z I2 I, s. 3.

38 Cyt. za: Mirosław Derecki, „Ekran i widz: kawałek życia reżysera”, Kamena 50 (1983) nr 2, s. I3.

39 Barbara Mruklik, „Wierność sobie”, Kino 20 (1985) nr 5, s. 4-9.

40 Zob. na ten temat: Monika Talarczyk-Gubała, Wanda Jakubowska. Od nowa, Warszawa 2015 , s. I46.

4I Zob.: Jan Marcin Szancer, „Jak powstaje film Nad Niemnem”, As 5 (1939) nr 20, s. 4-6. 
się w warsztacie szewskim, gdzie odnajduje swą wielką miłość (w roli córki właściciela, majstra Kopytkiewicza - Ina Benita), przesycona jest, jak na komedię przystało, głównie piosenkami. Poza scenami tanecznymi i śpiewanymi z rzadka tylko znaczy ją muzyka pozakadrowa. Tekstom Emanuela Szlechtera - Co może być lepszego, O ty moja cudna pani i piosence bez tytułu, z incipitem „Abecadło z pieca spadło trzeba je poskładać znów” - towarzyszą „chwytliwe” melodie i taneczne rytmy. Przyjąć trzeba - mimo świadomości szlagierotwórczego talentu Palestra - że są one dziełem Dana, tym bardziej, jeśli zauważymy, że podział ról kompozytorskich w naturalny sposób pasował w tym wypadku do binarności „muzyka poważna vs. lekka” ${ }^{42}$. Pierwsza z wymienionych piosenek (fokstrot) wykonywana jest zresztą przed kamerą przez Chór Dana w roli grupy szewskich czeladników, druga to „numer” z komponowanej dla teatru muzycznego, który chcą założyć przyjaciele Józia, operetki, trzecia zaś - to slow-fox towarzyszący scenie nauki alfabetu „pod melodię”. Muzyka Palestra ilustruje natomiast najistotniejsze dla dramaturgii filmu sceny, wykorzystując na przykład ukazany między piosenkowymi refrenami na tle początkowych napisów, pełen lekkości i wdzięku motyw, który rozwija się ze smyczkowego tremola w wysokim rejestrze, opadając na coraz niższe poziomy wysokości. Możliwe też, że to Palester był autorem orkiestrowych instrumentacji piosenek Dana, na przykład wspomnianego Abecadta, którego refren pobrzmiewa dzwoneczkowo-fortepianową barwą na zbliżeniu grającego zegara stołowego i na tle napisów końcowych do filmu.

Prawdopodobnie w 1939 r. Palester miał w planach jedno jeszcze przedsięwzięcie filmowe. W maju w prasie anonsowano bowiem ukończenie zdjęć do Testamentu prof. Wilczura w reżyserii Leonarda Buczkowskiego, podając nazwisko Palestra jako autora muzyki ${ }^{43}$. Ostatecznie premiera filmu odbyła się w 1942 r. z muzyką Zygmunta Wiehlera, autora szlagieru Ada! To nie wypada!, a Palester spotkał się z Buczkowskim tuż po wojnie na planie Zakazanych piosenek.

W filmowym dorobku Romana Palestra z lat międzywojennych znajduje się muzyka do jeszcze dwóch innych fabuł. Przy Auguście Mocnym z 1936 r. - niezachowanej do dziś polskiej wersji polsko-niemieckiego przedsięwzięcia - Palester współpracował z Leonem Schillerem, znanym mu doskonale ze wspólnych doświadczeń teatralnych. W młodości Schiller uczył się muzyki i występował w kabaretach, śpiewając piosenki, był - jak wynika także ze wspomnień samego Palestra ${ }^{44}$ - świetnym pianistą i improwizatorem. Zapewne zatem doskonale sprawdził się w roli autora piosenek

42 O podziale kompetencji twórców muzyki filmowej w I933 r. tak pisał Jan Maklakiewicz: „Zazwyczaj za granicą ilustracje muzyczne do filmów pisze kilku kompozytorów, w zależności od rodzaju muzyki: lekkiej czy poważnej. Natomiast nad instrumentacją i nagrywaniem czuwa poważny, wytrawny muzyk. U nas bywa różnie”, zob. tegoż: „O udźwiękowianiu filmów”, Kalendarz Wiadomości Filmowych 8 (I933), s. 23.

43 Zob. np. Aktualności I (1939) nr 5-6, s. 9; „Rewelacyjny film Testament prof. Wilczura wg T. Dołęgi-Mostowicza na ukończeniu", Wiadomości Filmowe 7 (1939) nr Io, s. 5.

44 Roman Palester, „O Leonie Schillerze”, Wiadomości [Londyn] Io (1955) nr 500. 


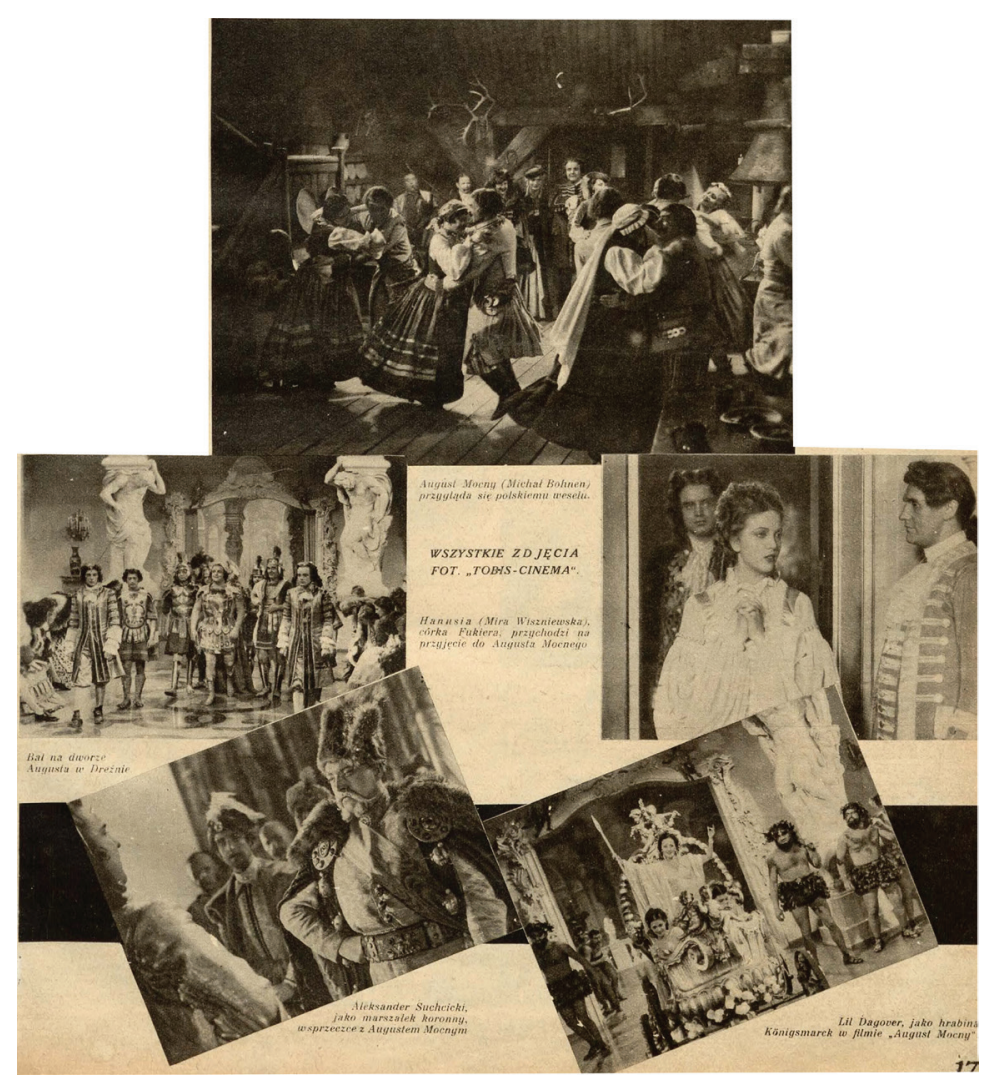

Il. 3. Fotosy z filmu August Mocny, w: Światowid I3 (1936) nr 8, s. I7.

do Augusta45, zwłaszcza, że nie było to dla niego pierwsze doświadczenie filmowe - współtworzył wszak wraz z Grzegorzem Fitelbergiem muzykę do jednego z pierwszych polskich dźwiękowców, Janka Muzykanta (1930). Wobec powyższego domyślać by się można, że zadaniem Palestra było napisanie „poważnej” części muzycznej ilustracji. Jednak, odkąd w relacji prasowej z berlińskiego atelier filmowego czytamy, że „muzykę ludową dobrali Leon Schiller i Roman Palester” ${ }^{46}$, przypuścić można, że zakres obowiązków obydwu twórców wykraczał poza tę prostą dwuzadaniowość.

Raz jeszcze spotkał się Palester z Schillerem na planie filmowym. Stało się to przy okazji Halki - dramatu psychologicznego na kanwie libretta opery Stanisława Moniuszki z dialogami Jarosława Iwaszkiewicza i reżyserią Juliusza Gardana (1937). Postrzegana jako film operowy Halka chwalona była zwłaszcza za stronę muzyczno-baletową. Natomiast zastrzeżenia budziła jego strona operatorska.

45 Takie przyporządkowanie autorstwa podaje internetowa baza filmpolski.pl, zob.: http://www.filmpolski. $\mathrm{pl} / \mathrm{fp} /$ index.php?film=22463, dostęp 7 I 2019.

46 Reld., „August Mocny. Nowe możliwości dla naszych aktorów”, Światowid I3 (1936) nr 8, s. I7. 
W ogóle aparat w tym filmie przejął się widać operowym bezwładem i zamiast zadokumentować swą ruchliwość, wybałusza swe „oko” na przykład na śpiewającego Jontka (czy Halkę) i trwa w tym „zamyśleniu”, zapominając, że śpiewak w filmie nie może wyglądać, jak gdyby stał przed rampą sceny i że trzeba przez czas trwania arii coś widzowi „pokazywać”, zwłaszcza, gdy akcja rozgrywa się na tle wspaniałego krajobrazu, w innych miejscach zresztą pokazanego w całej krasie

- komentowała dla Bluszczu Stefania Heymanowa ${ }^{47}$. „Retardacyjny balast”48, jaki ustanowiły dla filmu arie operowe, równoważyła jakość ich wykonania. Jontka zagrał i zaśpiewał bowiem Ladis Kiepura, a śpiewaną część roli Halki (na ekranie: Lili Zielińska) wykonała „największa polska śpiewaczka, Ewa Bandrowska-Turska”49, co było efektem pionierskiego zastosowania techniki play-backu. Schiller był kierownikiem artystycznym i współscenarzystą filmu, a nad opracowaniem muzycznym Palester czuwał wraz z Feliksem Rybickim, który także miał już na swoim koncie ważne filmowe doświadczenia (Dziesięciu z Pawiaka z I93I r.; Księżna Łowicka z 1932 r.; Rok I9I4 zrealizowany w 1932 r.; Tajemnica panny Brinx z 1936 r.). Jednakże - jak w pozostałych przykładach współautorstwa - niemożliwe jest dziś ustalenie, za które fragmenty opracowania muzycznego, za jakie decyzje dotyczące adaptacji muzyki do scenariusza odpowiedzialny był każdy z kompozytorów.

Literatura filmologiczna ${ }^{50}$ każe łączyć nazwisko Palestra także z dwoma zrealizowanymi w okresie międzywojennym filmami dokumentalnymi. W I934 r. powstał film reklamowy propagujący książeczki oszczędnościowe PKO według scenariusza Haliny Ostrowskiej-Grabskiej pt. Cudowny dzbanek, w którym - wedle informacji prasowych - wykorzystano muzykę Palestra i piosenki Juliana Tuwima. Natomiast z roku 1935 pochodzi reportaż Ryszarda Biskego i Leona Jeannota Walczymy z powodzia, traktujący o pracach regulacyjnych na rzekach i strumieniach, które służyły ochronie przeciwpowodziowej. Chociaż zatem domeną Palestra były i miały pozostać fabuły, przed wojną włączył się on także jako twórca muzyki w sferę krótkiego metrażu, od której miał też rozpocząć swą powojenną aktywność w świecie filmu. Z prasowych polemik na temat polskiego filmu krótkometrażowego lat trzydziestych wnioskować można, że mimo istnienia przykładów wybitnych ${ }^{5 \mathrm{I}}$, oprawa muzyczna była raczej bagatelizowanym ich elementem - w wielu pojawiał się jedynie „dosynchronizowany” akompaniament fortepianowy albo „melodie nie związane nigdy z tematem lub myślą tego, co dzieje się na taśmie" 52. Jak brzmiała w tym kontekście muzyka Palestra, niestety, nie wiadomo.

47 Stefania Heymanowa, „Z życia ekranu”, Bluszcz 70 (1937) nr 51, s. 637.

48 Zob.: Leszek Armatys, „Nasz iluzjon: Halka”, Kino 7 (1972) nr 6, s. 63.

49 „W polskim świecie filmowym”, Kino 8 (1937) nr 22, s. 2.

50 Zob. „Katalog dokumentów filmowych zrealizowanych w latach 1985/1896-1944 (wybór)”, w: Małgorzata Hendrykowska, op. cit., s. 551 i 572.

5I Zalicza się do nich m.in. muzykę Lutosławskiego do impresji filmowej Themersonów Zwarcie (1935).

52 Stefan Krukowski, „Polski film krótkometrażowy na ślepym torze”, Film (1937) nr 17, s. 4. 
Na koniec przyjrzyjmy się bliżej muzyce Palestra do filmu Zabawka dowodzącej, jaki analityczny potencjał tkwi w jego filmowych ilustracjach. Ogólną zasadą, do której kompozytor się w tym przypadku stosuje, jest nadanie ścieżce muzycznej spójności poprzez wielokrotne powtarzanie określonych motywów muzycznych. Nazwać ją można centralizacją „wokół pieśni”, o której pisała Zofia Lissa w swym pierwszym monograficznym podejściu do estetyki muzyki filmowej ${ }^{33}$, gdyż - jak już wspomniano - podstawową materię muzycznej oprawy stanowią dwie przebojowe piosenki. Oznacza to, że ta sama melodia występuje w rozmaitych sytuacjach, jest przekształcana, „transponowana” czy też wplatana w konteksty. Po zaprezentowaniu obydwu piosenek w czołówce filmu, zarówno To mi wystarczy, jak i Baby, ach te baby słyszymy na poziomie świata przedstawionego filmu. Lulu śpiewa swoją piosenkę po raz pierwszy podczas występu w warszawskim kabarecie (ok. 6:00-8:00 min.), gajowy Kuźma natomiast „przedstawia się”, przygrywając refren swojej na harmonii i wyłaniając się zza drzew, by pospieszyć z pomocą pasażerom zagrzebanego w błocie auta (ok. 21:00-22:00 min.). Obie piosenki powracają Baby w dwóch wersjach śpiewanych przy akompaniamencie harmonii, a ponadto jako muzyka taneczna do zabawy w karczmie, natomiast To mi wystarczy dwukrotnie jeszcze pojawia się w wersji wokalno-instrumentalnej, gdyż Lulu śpiewa ją na przyjęciu we dworze oraz na końcu filmu, po powrocie do kabaretu. Muzyka Palestra w połączeniu ze słowami Jerzego Nela tworzy lapidarną charakterystykę głównych postaci filmu, zgrabnie odzwierciedla tęsknoty i marzenia miejskiej „artystki" oraz prostego chłopa. Natomiast spoza ekranu wielokrotnie rozbrzmiewają różnorodne przekształcenia i warianty głównych motywów obu piosenek. Ilustrują wówczas nastroje i przeżycia wewnętrzne obydwojga bohaterów, kreują atmosferę niektórych scen, komentują ją w specyficzny sposób, a nawet antycypują pewne zdarzenia. Takie ścisłe powiązanie między materiałem muzycznym i akcją filmu nie było oczywiście niczym nowatorskim, lecz przyznać trzeba, że tkwiące w wykorzystanych utworach możliwości asocjacyjne Palester wykorzystał bardzo sprytnie. Przyjrzyjmy się kilku przykładom.

Przekształcony, także rytmicznie, motyw refrenu $B a b$ towarzyszy na przykład scenie flirtów w plenerze z Lulu przebraną w chłopski strój (ok. 40:00). Jego reminiscencje odzywają się też (na tle arpeggiów harfy) po bójce gajowego z młodym dziedzicem, w połączeniu z aktorskim gestem, sygnalizując, że za chwilę zdarzy się jakieś nieszczęście. Motyw refrenu To mi wystarczy jest z kolei swoistym „memento” dla Lulu, które powraca zawsze wtedy, gdy bohaterka przypomni sobie o swojej przeszłości i niechybnym przeznaczeniu.

53 Zofia Lissa, Muzyka i film. Studium z pogranicza ontologii, estetyki i psychologii muzyki filmowej, Lwów I937, s. I29. 
Jest jeszcze w Zabawce trzeci ważny temat muzyczny. Ma on charakter taneczny i charakteryzuje nie tyle postać, ile relację między Lulu a hrabią Latoszyńskim - pozornie zaangażowaną a jednak pełną dystansu. Pozostaje też w związku z założonym w scenariuszu kontrastem ,zagęszczonej wielkomiejskimi oparami atmosfery” z sielskością kresowej wsi ${ }^{54}$ (pierwsze wystąpienie ok. 20:00). Słuchając ścieżki muzycznej Zabawki, uznać można, że założenie to znajduje odzwierciedlenie także na poziomie instrumentacji, bowiem Palester, ilustrując sceny wiejskie, nierzadko używa „pastoralnych" barw rożka angielskiego czy klarnetu. Słów kilka należy się także wspomnianemu wyżej, promującemu film tangu, które rozbrzmiewa w nim trzykrotnie jako akompaniament do tańca na przyjęciu. Przy tym ujęcia z dworu zmontowane są naprzemiennie z ujęciami zabawy w karczmie przy dźwiękach refrenu Bab (ok. 6o:0o), co daje widzowi nie tylko wgląd w sytuacje istniejące jednocześnie w różnych miejscach, ale też w emocje głównych bohaterów, które za kilka minut wybuchną w dramatycznej kulminacji.

Dopełnieniem warstwy muzycznej Zabawki jest oryginalna muzyka o charakterze ilustracyjnym. Trzyma się w niej Palester konsekwentnie konwencji późnodziewiętnastowiecznej, typowej dla ilustracji filmowych swoich czasów, a jednocześnie kongruentnej z piosenkowymi motywami przewodnimi. Daje przy tym liczne dowody warsztatowej sprawności. Za pomocą szerokiej palety środków kolorystycznych Palester podkreśla humorystyczny charakter niektórych scen, za pomocą ruchliwych figur dźwiękowych dynamizuje sekwencję powrotu z przyjęcia do gajówki, a także uwypuklając rolę instrumentacji i rytmu - dramatyzuje toczącą się zupełnie bez słów scenę napastowania Lulu i walki młodego hrabiego (w tej roli Jerzy Marr) z Kuźmą, a następnie moment pożegnania kochanków (sekwencja przed 70:00). Odpowiednio zniuansowana pod względem wyrazowym muzyka jest także tłem dla scen ukazujących Lulu biegnącą po ratunek (jedyne słowa, które wówczas padają, to dwukrotnie wykrzyknięte przez Lulu „Ratunku!”) oraz ilustruje przeżycia wewnętrzne Kuźmy, które doprowadzają go do decyzji o zgłoszeniu się na lokalny posterunek policji. Gdy zaś Lulu w pełni zdaje sobie sprawę, że była tylko „zabawką”, że jest już na wsi nikomu niepotrzebna, słyszymy refren To mi wystarczy w wersji nostalgiczno-tragicznej (ok. 75:00-76:00).

Powyższy skrócony opis funkcji i znaczeń muzyki w filmie Zabawka, uzupełniony o syntetyzujący graficzny schemat (il. 4), zdaje się wymownie potwierdzać opinię Jana Krenza, który we wspomnieniach podkreślał pełen „właściwego dystansu” a zarazem „solidności”’s stosunek Palestra do zamówień na muzykę filmową. 


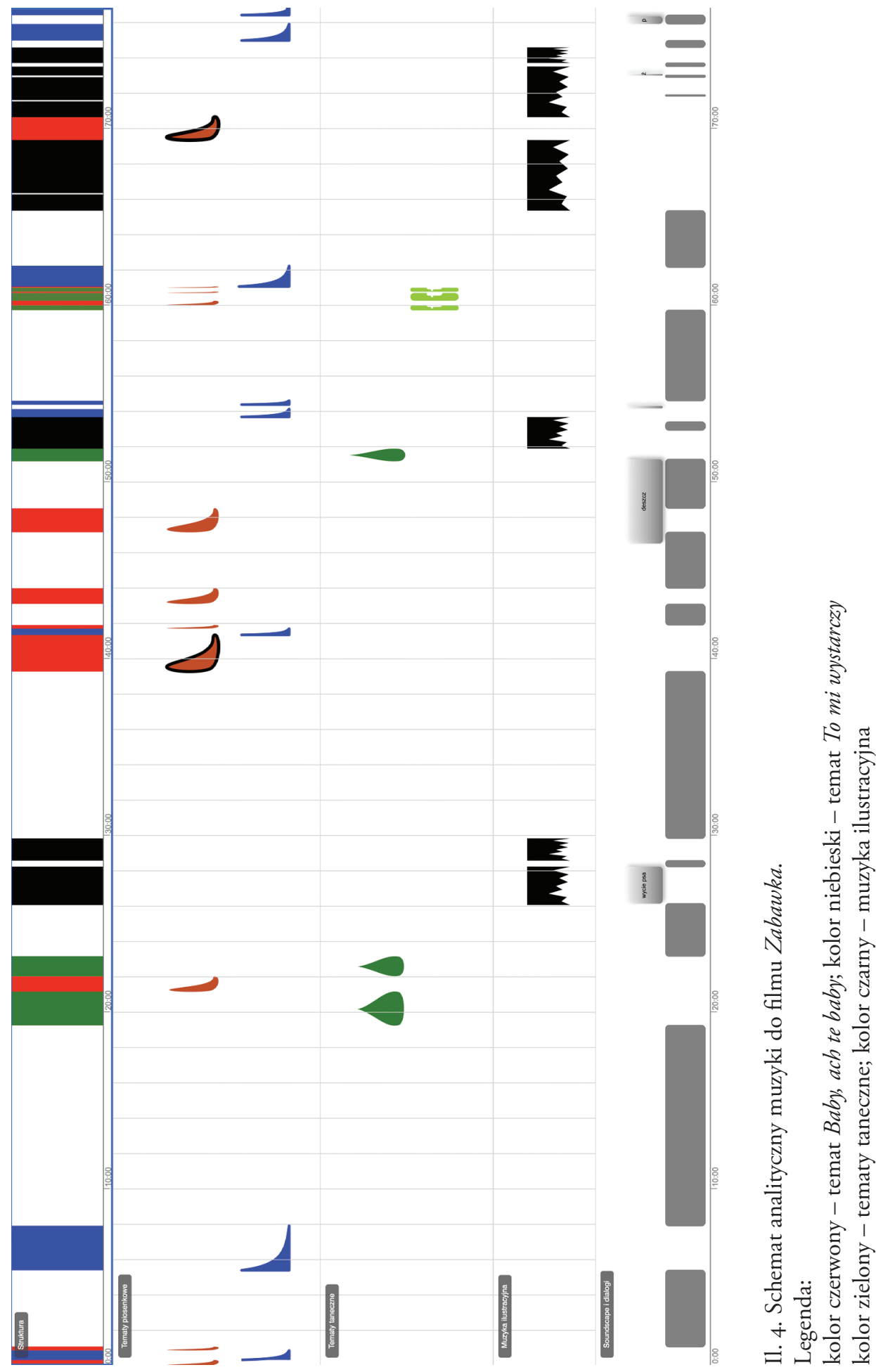


Tab. I. Wykaz filmów z muzyką Romana Palestra powstałych do 1939 roku.

\begin{tabular}{|c|c|c|c|c|}
\hline Rok & Tytuł & Muzyka & Reżyser / Producent & Premiera \\
\hline \multicolumn{5}{|c|}{ fabularne } \\
\hline 1932 & Dzikie pola & $\begin{array}{l}\text { Roman Palester, Marian } \\
\text { Neuteich }\end{array}$ & Józef Lejtes / Sola-film & 18 III 1932 \\
\hline 1933 & Zabawka & Roman Palester & $\begin{array}{l}\text { Michał Waszyński / } \\
\text { Stanisław Gulanicki }\end{array}$ & 9 XII 1933 \\
\hline 1934 & Mtody las & $\begin{array}{l}\text { Roman Palester, Marian } \\
\text { Neuteich }\end{array}$ & Józef Lejtes / Libkow-Film & 22 XII 1934 \\
\hline 1935 & $\begin{array}{l}\text { Dzień wielkiej } \\
\text { przygody }\end{array}$ & $\begin{array}{l}\text { Roman Palester, Marian } \\
\text { Neuteich }\end{array}$ & Józef Lejtes / Panta-Film & 24 VIII 1935 \\
\hline 1936 & August Mocny & $\begin{array}{l}\text { Roman Palester, Leon } \\
\text { Schiller (piosenki) }\end{array}$ & $\begin{array}{l}\text { Stanisław Wasylewski / } \\
\text { Polski Tobis Cinema }\end{array}$ & XI 1936 \\
\hline 1936 & Róża & $\begin{array}{l}\text { Roman Palester, Marian } \\
\text { Neuteich }\end{array}$ & Józef Lejtes / Libkow-Film & 12 IV 1936 \\
\hline 1937 & $\begin{array}{l}\text { Dziewczęta } \\
\text { z Nowolipek }\end{array}$ & $\begin{array}{l}\text { Roman Palester, Marian } \\
\text { Neuteich }\end{array}$ & Józef Lejtes / Parlofilm & $26 \times 1937$ \\
\hline 1937 & Halka & $\begin{array}{l}\text { Roman Palester, Feliks } \\
\text { Rybicki }\end{array}$ & Juliusz Gardan / Rex-Film & 2 XII 1937 \\
\hline 1938 & Ludzie Wisty & $\begin{array}{l}\text { Roman Palester, Marian } \\
\text { Neuteich }\end{array}$ & $\begin{array}{l}\text { Aleksander Ford, Jerzy } \\
\text { Zarzycki / Legia-Film }\end{array}$ & 23 VII 1938 \\
\hline 1939 & Ja tu rzadze & $\begin{array}{l}\text { Roman Palester, } \\
\text { Władysław Dan }\end{array}$ & $\begin{array}{l}\text { Mieczysław Krawicz / } \\
\text { Lira-Film }\end{array}$ & 23 XII 1939 \\
\hline 1939 & Nad Niemnem & Roman Palester & $\begin{array}{l}\text { Wanda Jakubowska, Karol } \\
\text { Szołowski / Spółdzielnia } \\
\text { Autorów Filmowych }\end{array}$ & $\begin{array}{l}\text { planowana } \\
\text { na } 4 \text { IX } 1939\end{array}$ \\
\hline 1939 & $\begin{array}{l}\text { Żotnierz królowej } \\
\text { Madagaskaru }\end{array}$ & Roman Palester & $\begin{array}{l}\text { Jerzy Zarzycki / Spółdzielnia } \\
\text { Autorów Filmowych, } \\
\text { Baltic-Film }\end{array}$ & 31 XII 1940 \\
\hline \multicolumn{5}{|c|}{ dokumentalne } \\
\hline 1934 & Cudowny dzbanek & Roman Palester & Halina Ostrowska-Grabska & brak danych \\
\hline 1935 & $\begin{array}{l}\text { Walczymy } \\
\text { z powodzia }\end{array}$ & Roman Palester & $\begin{array}{l}\text { Ryszard Biske, Leon Jeannot } \\
\text { / Panta-Film }\end{array}$ & brak danych \\
\hline
\end{tabular}

II wojna światowa nie dała kompozytorowi zapomnieć o świecie filmu - podjęcie pracy na rzecz odbudowującej się z gruzów polskiej kinematografii było jedną z pierwszych aktywności twórczych Palestra po 1945 roku. Przed wyjazdem z Polski kompozytor zdążył napisać jeszcze szereg partytur filmowych, w tym do bardzo ważnych z punktu widzenia historii polskiej kinematografii produkcji fabularnych, jak Zakazane piosenki Leonarda Buczkowskiego, Ostatni etap Wandy Jakubowskiej czy Ulica Graniczna Aleksandra Forda, ale też do takich dzieł filmowych, które do rozpowszechniania trafiły dopiero po dłuższym czasie, jak wielokrotnie przerabiany $R o-$ binson warszawski / Miasto nieujarzmione Jerzego Zarzyckiego czy też Dwie godziny 
Stanisława Wohla i Józefa Wyszomirskiego oraz zatrzymany przez Centralny Urząd Kontroli Widowisk „plakat filmowy” Antoniego Bohdziewicza $2 \times 2=4$. Z kolei z czasem przejścia Palestra na emeryturę i ponownego zamieszkania w Paryżu zbiega się jego praca nad muzyką do zrealizowanego w Danii Pierwszego kręgu Aleksandra Forda (wg powieści Aleksandra Sołżenicyna), z którym kompozytor podzielił los emigranta z zapisem cenzury na nazwisko. Życiowe zmiany ułatwiły mu zatem zapewne podjęcie decyzji o przyjęciu typu zlecenia kompozytorskiego, którego od dawna nie uprawiał. Typ ten, jakkolwiek przez samego Palestra konsekwentnie bagatelizowany, tworzy nieusuwalną i niewątpliwie wartą przybliżenia część jego twórczego wizerunku.

\section{ROMAN PALESTER AS A PIONEER OF POLISH FILM MUSIC}

Roman Palester's film music has left a lasting trace on Polish cinematography, even though the composer himself did not attach much importance to this aspect of his work. The present paper is dedicated to the first stage of his work for the film industry (until 1939). On the basis of surviving audio-visual materials and indirect sources, I aim to sketch a panorama of the reception of Palester's film music in the cultural environment between the two world wars, to analyse the principles of his collaboration with other composers in the case of co-authorship, and briefly to characterise the function, significance and qualities of Palester's soundtracks, with particular reference to the film Zabawka (Toy).

Palester's most productive collaboration was that with film director Józef Lejtes (I9OI-83). The composer wrote music for five of Lejtes's films: Dzikie pola (Wild Fields, 1932), Mtody las (The Young Forest, 1934), Dzień wielkiej przygody (The Day of Great Adventure, 1935), Róza (Red Rose, 1936), and Dziewczęta $z$ Nowolipek (Girls of Nowolipki, 1937). On each of these pictures, Palester worked together with Marian Neuteich, with whom he also composed music for Ludzie Wisty (People of the Vistula, 1938, dir. Aleksander Ford and Aleksander Zarzycki). On the soundtrack for August Mocny (King August the Strong, 1936), Palester collaborated with Leon Schiller, and for Halka (based on the libretto of Stanisław Moniuszko's opera) - with Feliks Rybicki. The music illustration for Ja tu rzadze (I Am the Boss Here, 1939) he co-authored with Władystaw Dan-Danitowski. Since the scores are lost, and the film subtitles are very general, it is hard to determine what the actual division of tasks and competences looked like in the case of each of these two-composer teams, but (apart from the last of the above listed films), it was most certainly not a simple split between one composer contributing the 'light', and the other - 'serious classical' pieces. What is more, in Lejtes's films the music soundtrack is a response to the director's idea of combining mutually independent visual and acoustic elements into the so-called 'third dimension', and the music carries numerous symbolic associations.

Palester's individual contributions are the soundtracks for Michał Waszyński's Zabawka (Toy, 1933) and for two 1939 productions: Jerzy Zarzycki's Żotnierz Królowej Madagaskaru (The Soldier of the Queen of Madagascar) and Wanda Jakubowska's / Karol Szołowski's Nad Niemnem (On the Niemen River), which have not been preserved to our day. The music for 
Toy is a refined example of how popular songs can be used to integrate dramatic structure and how they can be combined with music maintained in the typical early sound film style.

In the period that ended in 1939, Palester also composed - according to existing research - music for two documentaries (though other such commissions may possibly still be discovered). Overall, his output of film music testifies, on the one hand, to his distanced approach to this subject, and on the other - to his diligent and technically competent attitude to his commissions for film music. His soundtracks are an indelible part of his artistic image and are most certainly worth presenting in more detail.

Translated by Tomasz Zymer

Słowa kluczowe / keywords: Roman Palester, polska muzyka filmowa do 1939 / Polish film music until 1939, piosenka w filmie / film song, Marian Neuteich, Józef Lejtes

Dr hab. Iwona Lindstedt, adiunkt w Zakładzie Teorii i Estetyki Muzyki Instytutu Muzykologii Uniwersytetu Warszawskiego. Jej zainteresowania badawcze skupiają się na historii, teorii, estetyce muzyki i analizie dzieła muzycznego w odniesieniu do twórczości XX i XXI wieku. Specjalizuje się także w zakresie metodologii. Od roku 2016 pełni funkcję redaktor naczelnej Polskiego Rocznika Muzykologicznego. Autorka m.in. monografii Dodekafonia i serializm w twórczości kompozytorów polskich XX wieku (Lublin 2001), Sonorystyka w twórczości kompozytorów polskich XX wieku (Warszawa 2010).

i.lindstedt@uw.edu.pl

\title{
Nowe wydawnictwa Instytutu Sztuki PAN
}

Bronisława Wójcik-Keuprulian. Korespondencja do Szwajcarii. Listy do Henryka Opieńskiego (1925-37) i Ludwika Bronarskiego (1929-38) opracowanie, wstęp i komentarze Matgorzata Sieradz.

Zygmunt Mycielski - Andrzej Panufnik. Korespondencja Część 2: Lata 1970-1987

opracowanie, wstep $i$ komentarze Beata Bolestawska-Lewandowska

\author{
www.ispan.pl \\ iswydawnictwo@ispan.pl
}

